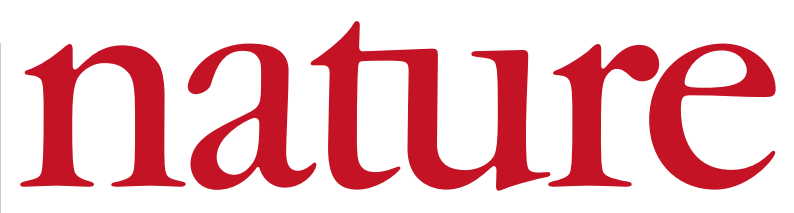

16 September 2004 Volume 431 Issue no 7006

\title{
Better to be talked about...
}

The prominence of embryonic stem cells as a key issue in the US presidential election campaign is, at best, a mixed blessing for science.

$\mathrm{T}$ he two main candidates for the world's most powerful elective office are poles apart on several science-related issues. Their answers to a series of questions on these topics reveal a rich tapestry of disagreement (see News Feature, page 238).

George W. Bush advocates the modernizing of America's nuclearweapons stockpile, whereas John Kerry would halt such work. Kerry states emphatically that climate change requires "concrete steps" to limit emissions of greenhouse gases in the United States, and to restart international negotiations on emissions limits; Bush acknowledges that climate change is a "serious long-term issue" but says that "considerable uncertainty" surrounds its impact. Kerry promises to clean up the process from which the government gets scientific advice, insinuating that Bush has sullied it. And so on.

But for the casual observer (and anyone who hasn't made up their mind yet is probably observing pretty casually), there is only one scientific issue in the election: human embryonic stem-cell research.

Bush wanted to defuse the issue when he announced guidelines on 9 August 2001 whereby researchers could obtain federal funding to work with embryonic stem-cell lines derived before then. Kerry recognized the unpopularity of Bush's compromise and made much of it at this year's Democratic convention in Boston, where, one of his acolytes bizarrely boasts, he mentioned embryonic stem cells more often than unemployment. His strategists want to use embryonic stem-cell research as a "wedge issue" in the campaign. In the parlance of the political consultant, a wedge is a block of very hard material of triangular cross-section that will be hammered repeatedly into something softer - one's opponent's support base - in order to split it up.

Some science lobbyists argue (without much conviction) that the debate is a healthy one, exposing the public to some of the intricacies of cell biology. But the emergence of the stem-cell issue as part of this bitterly divisive campaign is problematic for developmental biology, and for science as a whole.
For a start, the argument threatens to subsume all other aspects of biology in the public mind. When one staff member at a scientific society took a vacation last month to Alaska, he told a fellow vacationer that he worked "in biomedical research". "Oh," said the man, a resident of Cleveland, in the great swing state of Ohio. "So you work on stem cells?"

More seriously, the debate lumps the scientific community on one side of what is really an ethical and moral, rather than a scientific, question. There are many scientific questions that could be asked in the campaign to which the scientific method can perhaps provide an answer, such as: "Is global warming being caused primarily by greenhouse-gas emissions?"

The stem-cell question falls into a different category. The question: "In what circumstances is it appropriate to use human embryos for fundamental scientific research?" is essentially a moral and ethical one. Scientists can inform the public on aspects of the question, but they cannot answer it.

Many scientists see Bush's guidelines as an unnecessary barrier to important research, and rightly so. It is entirely appropriate that they should seek to engage the public on the question. But the rallying of various prominent supporters, and of disease-specific lobby groups, to the cause has resulted in some over-the-top claims being made about the likely impact of stem-cell research on treatments for diseases such as Alzheimer's.

As Oscar Wilde might have said, it is better for science to be talked about in the campaign than for it not to be talked about. But the nature of the current conversation carries risks. These can be minimized if scientists refrain from making extravagant public claims on behalf of embryonic stem-cell research, and endeavour, against all the odds, to maintain a genuine dialogue with people of good faith who are worried about the moral and ethical limits of developmental biology.

\section{How to interfere with RNA}

\section{Using RNA to manipulate gene expression is a powerful experimental tool, but can lead researchers astray.}

$\mathrm{T}$ here are many reasons to celebrate the recent discovery of RNA interference (RNAi). The finding that small double-stranded RNA molecules can silence gene expression has had a huge impact on both biological research and technological applications.

For example, it adds a further layer of complexity to our understanding of gene regulation; we have been alerted to the hundreds of small RNAs with potential regulatory roles in development and physiology; and new pathways and enzymes involved in RNA processing are rapidly emerging. RNAi has been exploited as an experimental tool to inactivate gene function, and has enabled large-scale genetic experiments to be performed more effectively in mammalian cells, when they had hitherto been feasible only in lower organisms. There is therapeutic potential for RNAi too, with the first clinical trials currently being put forward for regulatory approval. The Nature Insight in this issue reviews this exciting field.
But it also carries an important note of caution about RNAi as a technology, which is discussed in a review by Gregory Hannon and John Rossi (see page 371). RNAi has many advantages over other methods of gene inactivation in its apparent ease and specificity. But just as with these other methods, the specificity of silencing is not absolute and there is a danger of 'off-target' effects. Hannon and Rossi explain the potential pitfalls and offer some "rules of the road" for effective RNAi experiments.

We fully endorse their recommendations. Good experimental design and controls can alleviate many of the specificity problems, and we will work with peer reviewers to keep abreast of such requirements in this fast-moving field (see also Nature Cell Biol. 5, 489-490; 2003). In the future, a deeper understanding of the mechanisms of RNAi should allow better design of RNAi triggers and enable nonspecific effects to at least be predicted, if not eliminated. 